\title{
Public Policy Impact on Prosperity and Resilience of Farms and Agricultural Companies: Lithuanian Case Study
}

Vilma ATKOCIUNIENE், Faculty of Economics and Management, Aleksandras Stulginskis University, Universiteto g. 10, LT-53361 Akademija, Kauno r., Lithuania, vilma.atkociuniene@gmail.com

Alvydas ALEKSANDRAVIČIUS, , Faculty of Economics and Management, Aleksandras Stulginskis University, Universiteto g. 10, LT-53361 Akademija, Kauno r., Lithuania aleksandravicius@ gmail.com

Romualdas ZEMECKIS, Institute of Environment and Ecology, Aleksandras Stulginskis University, Kaunas, Lithuania, Studentų g. 11, LT-53361 Akademija, Kauno r., Lithuania, romualdas.zemeckis@asu.lt

The CAP support is mostly focused on the technological modernization of farms, linked with production intensification, and weakly focused on the farms prosperity and resilience. As a result farmers and managers of agricultural companies are only a slightly motivated to produce added value and high quality food products, to use short food supply chains addressing constantly changing consumer needs, or to pay much attention on issues related to climate change. The paper findings are based on the Lithuanian case study carried out as a part of the international research project "Rethinking the links between farm modernization, rural development and resilience in a world of increasing demands and finite resources" (RETHINK). The Lithuanian case study was determining farmers' behaviour and causal factors in decision-making. The research based on the positive research paradigm, case study, content and descriptive analysis, empirical study methods (answers of two groups of experts experts-professionals and experts-farmers), logical and systematical reasoning, graphic presentation, abstracts and other methods. The present paper is examining the impact of political factors on prosperity and resilience on farms and agricultural companies. The political factors have the highest impact for prosperity of the farms and agricultural companies in Lithuania (as compared to the technical - entrepreneurial, ethical - social factors, and intangible values). The support from the EU and the national funds is not fully in line with the current concept of farms' modernization and agricultural innovation. The public policy influence on the competitiveness of the agricultural sector is more strengthening than weakening. The results show the main elements that farmers believe should be included in the new concept of rural prosperity, as well as the main strategies adopted to reach prosperity divided into the five sub dimensions: development of the rural social infrastructure and implementation of information technologies; strong self-governance, social awareness and partnership; high culture of life and communication; rural employment and job creation in rural areas, population welfare; economic and social viability, ecology and environmental security of the countryside.

Keywords: rural development policy, farms and agriculture companies' resilience, rural prosperity.

\section{INTRODUCTION}

The majority of farms are oriented to product (creation, production or use of new products / services in the farm) and technological (creation of new technological applications in various farm activities) innovation. A very small proportion of farmers $(11 \%)$, implements integrated (complex of products, technological and social innovation) and just $7 \%$ of them - social (creation and implementation of new management, organizational and other structures and forms in various farm activities) innovations (Mokslines..., 2013). The main attention in the case study is concentrated on the two themes: factors (mainly economic, social and environmental), influencing farms and agricultural enterprises resilience and prosperity, relevant problems in the current period and future potential in the agricultural and food sector and rural development.

Prosperity and resilience are becoming a hot topic. The increasing interest it is attracting in the development community offers an opportunity for designing and implementing more effective forms of intervention. Specifically, a variety of actors are proposing prosperity and resilience as a framework for fostering deeper integration between agriculture management and longer-term development interventions as policy.

Scientific problem. The agriculture farms and local economy modernization is not linked with innovations and sustainability, prosperity and resilience. The modernization consists largely of using improved seeds, modern farm machinery such as tractors, harvesters, threshers, etc., chemical fertilizers and pesticides in an optimal combination with water. The theoretical fundamentals formed up to this day are unusable for creation of innovative public policy measures and agriculture farms management opportunities. For this reason the analysis of public policy impact on prosperity and resilience of Lithuanian farms and agriculture companies should be defined and justified.

Copyright (C) 2015 The Authors. Published by Aleksandras Stulginskis University. This is an open-access article distributed under the terms of the Creative Commons Attribution License (CC-BY 4.0), which permits unrestricted use, distribution, and reproduction in any medium, provided the original author and source are credited. 
The aim of research is to identify the impact of public policy on farms and agriculture companies' resilience and rural prosperity.

The research is based on the positive research paradigm, case study, content and descriptive analysis, empirical study methods, logical and systematical reasoning, graphic presentation, abstracts and other methods.

The present case of Lithuania is limited by a small territory, dominated by small and medium-sized farms $(98.7 \%$ of farms in 2013 (Lietuvos kaimo situacija...2014), therefore in the case study we focus on determination of farmers behaviour and causal factors in decision-making. In order to evaluate the public policy impact on prosperity and resilience, there were two groups of experts (180 experts: 98 experts-professionals and 82 experts-farmers) selected whose opinions have allowed the comparison of assumptions regarding the behaviour of farmers, participation in the market, development of long and short food supply chains.

Through the case study, a survey of academics, advisors, heads of Agriculture departments (on municipal level), Lithuanian Ministry of Agriculture, farmers organizations, agricultural companies and farmers nationwide was carried out in 2014. Experts-professionals represented all of the major Lithuanian institutions involved in the agricultural sector in science, education and consulting, rural development administration. Questionnaire items were discussed with farmers' organizations and the business community before the experts' survey. This case study is a part of RETHINK 'Rethinking the links between farm modernization, rural development and resilience in the world of increasing demands and finite resources' project. This research project funded through RURAGRI is an ERA-NET supported by the European Commission under the 7th Framework Programme and national funding agencies in 14 countries ${ }^{1}$.

\section{THEORETICAL CONTEXT OF PROSPERITY AND RESILIENCE OF FARMS AND RURAL DEVELOPMENT}

Economics Commissioner T. Jackson (2009) in the report "Prosperity without growth: Economics for a Finite Planet" structured the approach of prosperity - "has much in common with Amartya Sen's vision of development as "capabilities for flourishing". But that vision needs to be interpreted carefully: not as a set of disembodied freedoms, but as a range of "bounded capabilities" to live well - within certain clearly defined limits".

"Prosperity" is a social condition that is obtained through achieving greater social cohesion and finding higher levels of well-being while reducing their material impact on the environment (Darnhofer, Lamine, Knickel, 2013). According to Working With People framework (De los Ríos-Carmenado, Rahoveanu, Gallegos, 2014), the three central dimensions of prosperity are: ethical-social, technical-entrepreneurial and political-contextual, which interacts through inclusive and participative social-learning processes. Prosperity builds on the following principles and values: respect for and primacy of the people, guarantee social well-being, sustainable development, bottom-up and multidisciplinary approach, endogenous and integrated approach" ${ }^{2}$. The "Prosperity" theme aims at clarifying the following four broad issues in case study: contribution of the technical-entrepreneurial dimension to prosperity in agriculture/rural areas; contribution of the ethical-social dimension to prosperity in agriculture/rural areas; contribution of the political-contextual dimension to prosperity in agriculture/rural areas; stakeholder's conceptualization of prosperity. We base our paper on stakeholder's conceptualization of prosperity and assume that prosperity is influenced by the degree of farm resilience.

The concept of resilience is similar in some ways to the idea of capacity. Resilience is the ability of a joint social and ecological system - such as a farm - to withstand shocks, coupled with the capacity to learn from them and evolve in response to changing conditions. Building resilience involves creating strength, flexibility and adaptability. According to Oxfam (2009) a resilient farm can cope effectively with climate shocks while producing more and sustain its capacity for future responsiveness and production. Resilience is also the capacity of farmers to respond to and learn from shocks. The recent awareness of the limitations of national policies has also highlighted their implications for regional resilience, defined in this instance as ability to withstand the shock of an economic crisis. But in general, that it is wrong to see resilience in terms of an ability, following an economic shock, to return to the previous equilibrium growth path (Christopherson, Michie, Tyler, 2010). A resilient community was defined by the International Federation of Red Cross (IFRC, 2012). The concept can be transformed for the rural and farmers communities. A resilient community would have six connected characteristics: organized, based on natural resources, infrastructure and services, economic opportunities, knowledge and healthy. The community recognizing the importance of human health, well-being and individual knowledge, and acknowledging the necessity of assets and access to wider resources beyond the immediate control of the community. According to the K. Knickel, R. Zemeckis, T. Tisenkopfs (2013) the importance of adaptive capacity is rapidly growing because of the mounting vigour and incidence of global environmental and or climatic change. Communities and individual entrepreneurs need to be able to deal with the related unpredictability. On the level of farms and rural communities resilience relates above all to the capacity to learn, take decisions, and adjust economic and social activity to changing market and societal conditions.

\footnotetext{
${ }^{1}$ For more information see www.rethink-net.eu

${ }^{2}$ Working with People (WWP) is a concept based on new project management approach for regional development in post-modernity in rural areas. Key to the WWP conceptual framework is 'planning as social learning' and a 'new postmodern sensibility (Cazorla and De losRíos 2013). The name Working With People was chosen to convey the need to overcome the traditional technical-economic vision of project management for regional development, and the need to focus on individuals' behavior and the context.
} 


\section{POLITICAL CONTEXT DIMENSION}

Agricultural sector for its economic value (provision of the public with quality food, renewable energy resources, raw material in the textile, chemical and pharmaceutical industry) takes a special part in the EU countries' policy measures (Žalioji..., 2010). In order to preserve agriculture as a business and farming traditions, as well as due to the importance of this sector for the prosperity of the population, the EU countries have implemented a variety of the EU CAP and national agricultural support measures. Some of them have a direct and indirect impact on the farm and rural prosperity.

The conditions of agricultural operators' activities are determined not only by political factors within the country or across the EU but by the worldwide trend, necessary to be analysed and evaluated (Melnikienè, 2012). Therefore, considering the influence of political-legal factors on the prosperity of the farms, these policy issues should be highlighted separately:

1) Regulation of international trade of agricultural and food production;

2) The EU's Common Agricultural Policy (CAP);

3) National agricultural and rural development policy.

International trade regulation of the agricultural and food production. In recent years, the World Trade Organization (hereinafter - WTO) raises the question of market distortions, caused by the CAP by direct payments to farmers (Potential Challenges, 2007). The EU and WTO regularly negotiate liberalization of the foreign trade conditions, recognizing that the agriculture is one of the most sensitive sectors. Negotiations with WTO address the issues, connected to the destruction of the EU export subsidies, the EU domestic support for the agricultural sector and reduction of import duties. If these requirements of WTO would be implemented by the EU in near future, it would significantly impair financial position of small, medium-sized and large farms in Lithuania. According to the studies of economic viability of the farms, they are dependent on the direct support received and its withdrawal may negatively affect the resilience and prosperity of the farms.

Lithuanian agricultural and food products are mainly exported to Russia, Latvia and Germany (Lietuvos KPP 2014-2020, 2015). Latvian and German markets are regulated at the EU level, but Russian market is difficult to predict firstly due to political risk. Although from 2012 Russia is a member of WTO, its foreign trade policy and market protection mechanisms made Lithuanian agricultural and food exporters to face the market situation, dependent on the EU-Russia political arrangements. From August 2014, Russia introduced strict economic sanctions for the export of the main agricultural and food products from the EU to Russia. Undoubtedly, it will have negative financial consequences for meat, dairy, fruit and vegetable sectors in Lithuania and other EU countries. Therefore, due to unexpected trade losses, the EU will not only need to review the legal regulation of the international trade of agricultural and food production, but also to provide additional measures that would offset the income loss for individual agricultural and food producers due to unexpected political risks.

The EU's Common Agricultural Policy (CAP). Within the period of 2007-2013 two main areas of support were included in CAP:

1) Support for agricultural producers through direct payments and market management measures, such as milk quotas, intervention in purchases and so on ( $1^{\text {st }}$ Pillar) (Vidickienè, Melnikienè, 2014);

2) Promotion of rural development in various targeted measures for agricultural competitiveness, environment and rural economic diversification and social life activation ( $2^{\text {nd }}$ Pillar) (Vidickienè, Melnikienè, 2014).

However, after the global financial crisis in 2008-2009, the limitation of financial resources for CAP and the increasing pressure from WTO encouraged the review of the EU agriculture and rural development support model. It is also a big burden on public finances of the majority of the EU countries or increased budget deficits in the EU member countries is pushing to do so. This deal brings huge pressure on public finances in most EU countries and/or increases the budget deficits in EU countries. Therefore, it is planned in CAP to increase funding for rural development and to reduce the volume of direct market-distorting agricultural support from 2014. The EU's main requirement is that the direct support to the farmers would not be linked to their production (Commission Implementing Regulation, 2014). The decoupling of direct support from production is unfavourable for Lithuanian livestock farms, but contributes to the development of the crop farms. Lithuania managed to achieve higher direct payments in 2014-2020 rural development program, the $1^{\text {st }}$ Pillar of CAP measures, while in the $2^{\text {nd }}$ Pillar rural development measures are reduced. In order to mitigate the potential cumulative aid "imbalance" between the different branches of agriculture, Lithuania should significantly differentiate the EU structural support for agriculture, providing a different level of intensity of this support for crop and livestock farms.

An important role in the prosperity and resilience has been devoted to market regulation measures. However, under the new programming period, the CAP 2020, the framework of market regulatory instruments will be reviewed with the aims to remove most of the market-distorting regulatory instruments and to shift to supportive measures, mostly oriented to farm operational risk. This risk is related, in particular, to climate change, plant and animal diseases, epidemics, management and etc.

Implementation of the national agricultural and rural development policy. Even before joining the EU Lithuania had already started to support agriculture so it could be better adapted to the requirements of the EU. The support has been implemented through direct payments (for crops, greenhouse vegetables, fallow and grasslands, starchy potato, livestock, organic farming and farming in less favourable lands) and compensations (interest subsidies, loan guarantees and insurance partial coverage, the availability of untaxed diesel fuel excise) (Lietuvos kaimo..., 2010). However, national farm support measures applied before joining the EU i.e., at a time when agricultural structure was dominant by small economy farms, underserved with agricultural production means, were not very effective. Small farmers were not able to 
restructure their farms according to the EU standards due to low production volumes and low net profits, they also lacked funds for farm modernization and increase of production volumes. This situation appeared from the restoration of Lithuania's independence, as the land restitution caused changes in the structure of land use. It significantly increased the number of land owners, and, as a result, the average farm sizes decreased. Many land owners live in cities and do not have opportunities to go back to farms, so they tend to rent their land to farmers. Land, rented by the farmers, accounted for over $57 \%$ of the total cultivated farmland in 2011 (Lietuvos kaimo situacija...,2014). Due to this reason, Lithuania is still unable to form a stable agricultural structure as it prevents the use of the EU support for the modernization in a number of farms, because they cannot ensure the long-term and stable use of agricultural land.

Since joining the EU in 2004 Lithuanian agricultural entities began to receive direct and structural support under the First and the Second Pillars of the CAP. Furthermore, in order to reduce the transition loss, while direct payments reached $100 \%$ of the negotiated level, farmers received the complementary national direct payments from the state's budget. These income support measures are especially important for small farmers, because due to non-compliance criteria, they are unable to take advantage of most of the structural support for the modernization and innovation at farm level. In addition, according to the EC state aid schemes in line, Lithuania may provide support for certain agricultural sectors from the state's budget. However, as outlined in the country's aid measures, its opportunities to support agriculture by state funds are limited.

Since the launch of the structural support measures in 2000 (SAPARD 2004-2006, SPD Priority 4, Rural Development Program 2007-2013), Lithuanian agricultural policy was focused on modernization and intensification of agricultural production. More than 11 thousand projects of the farmers, aimed for modernization of farms holdings, have been implemented, out of which nearly $90 \%$ - in 2007-2011. Thus, an average of 48 thousand EUR was assigned per project. 34 thousand EUR assistance on the average was devoted to set up a 2.8 thousand of young farmers' households (Lietuvos kaimo..., 2013). Country's households' capital, in particular modern agricultural machinery, increased with the investment support for farm modernization and the installation of financial engineering instruments from 2009, facilitating the borrowing conditions for farmers. In 2010, compared with 2005, the farm assets per 1 ha of agricultural land increased by $89.7 \%$, while the assets per $1 \mathrm{SD}$ - by $38.3 \%$ (Lietuvos kaimo situacija..., 2014).

However, the attention has been focused on the upgrade of agricultural equipment. According to FADN data, it can be seen that investment in agricultural technique dominated in the structure of farm investments, accounting for $63 \%$ in 2010 (Lietuvos kaimo situacija..., 2014). Meanwhile, the EU and the state support for implementation of the latest scientific knowledge and innovation have been used inefficiently.

The features and components of the rural prosperity content, identified according to the opinion of expertsprofessionals are based on four attributes:

- The attributes of the rural prosperity in the area of policy,

- The attributes of the rural prosperity in the area of public administration,

- The attributes of the rural prosperity in the area of civil society,

- The attributes of the rural prosperity in the area of private business.

They reflect the mission and the guiding principles for creation of rural prosperity in policy, public administration, private and non-governmental sectors. According the experts-professionals opinion and number of answers frequency, the main attributes of the rural prosperity of Lithuania in the area of policy are: democracy and self-government (15); consistency and stability (15); positive territorial approach to agriculture, farming and financial support (10); policy, representing the rural population(public) interest (6); strategic direction - diversified local economy (4).

The new concept of Lithuanian rural prosperity content includes:

- Development of the rural social infrastructure and implementation of information technology (70 number of answers frequency);

- Strong self-management, social awareness and partnership (31 number of answers frequency);

- High living culture and communication (25 number of answers frequency);

- Rural employment and job creation in rural areas (18 number of answers frequency);

- Economic and social vitality of the region (17 number of answers frequency);

- Ecology and environment safety (16 number of answers frequency);

- Population welfare (16 number of answers frequency);

- Economically strong, innovative farmers and entrepreneurs (13 number of answers frequency);

- The legal environment and rural development policy (11 number of answers frequency).

During the investigation of the impact of the agricultural and rural development policy on the prosperity of the farms/agricultural enterprises (e.g., increase/decrease in farm income, product quality improvement, enhancement of farm competitiveness) the answers of 82 experts were received. According to them, public policy has a positive and a negative impact on the resilience and prosperity of the farms and agricultural enterprises (Table 1).

Political decisions support the incomes of the farmers and reduce the food prices. However, increasing bureaucracy and corruption shape the social inequality and exclusion in rural areas, while unbalanced financial support from the EU and the state distorts the market conditions. According to the experts, state policy measures assure food production and quality, but high requirements for agricultural production practices increase the cost and decrease the production of small farms. However, experts-farmers stated that the influence of public policy on the competitiveness of the agricultural sector is more strengthening than weakening. 
Table 1. The opinion of experts-farmers about the impact of public policies on the resilience and prosperity of the farms and agricultural enterprises (in order of priority, according to the argument statement confirming the number of repetitions)

\begin{tabular}{|c|c|}
\hline The positive impact of public policy issues & The negative impact of public policy issues \\
\hline $\begin{array}{l}\text { 1. Political decisions support the income of farmers and } \\
\text { reduce the food prices (19) } \\
\text { 2. Provide food production and quality (10) } \\
\text { 3. Strengthen the competitiveness of the agricultural } \\
\text { sector (10) } \\
\text { 4. Promote the conservation of biodiversity and the rural } \\
\text { environment ( } 8 \text { ) } \\
\text { 5. Create conditions for farmers to improve working } \\
\text { conditions ( } 8 \text { ) } \\
\text { 6. Develop a sense of community and provide } \\
\text { knowledge (4) }\end{array}$ & $\begin{array}{l}\text { 8. Increased bureaucracy and corruption shape the social } \\
\text { inequality and exclusion (18) } \\
\text { 9. Unbalanced financial aid distorts market relations (15) } \\
\text { 10. High veterinary and other requirements for agricultural } \\
\text { production practices increase costs and reduce the } \\
\text { volume of production (9) } \\
\text { 11. Political decisions weaken the competitiveness of } \\
\text { Lithuanian farms (8) } \\
\text { 12. Formation of irresponsible attitude and activities of the } \\
\text { farmers and officials for using the naturally created } \\
\text { resources ( } 8 \text { ) } \\
\text { 13. Lack of political stability, rapid change of political } \\
\text { decisions increase the risk (6) } \\
\text { 14. Policy priorities limit the autonomy of young farmers } \\
\text { and those who want to become young farmers (5) } \\
\text { 15. Disappearing villages, unfavourable for rural } \\
\text { development migration (5) }\end{array}$ \\
\hline Total 62 arguments & Total 74 arguments \\
\hline
\end{tabular}

Controversial is the impact of the public policy on natural and rural environment. As a positive aspect of the policy, experts-farmers indicated the promotion of biodiversity conservation and the rural environment. Simultaneously, they were concerned regarding the formation of farmers' irresponsible attitude and actions towards the use of natural and created resources. It can be assumed that the financial support from the EU and the state is administrated insufficiently, with a lack of good governance and innovative solutions.

According to the experts, political-contextual factors have the greatest impact (as opposed to technicalentrepreneurial, ethical-social factors of intangible assets) on the prosperity of the farms and agricultural enterprises in Lithuania (Table 2).

Table 2. The strength of political - contextual elements impact on farm and agricultural enterprises prosperity according to experts professionals and experts - farmers, average rate

\begin{tabular}{|l|c|c|c|}
\hline \multicolumn{1}{|c|}{ Items } & \multicolumn{2}{c|}{ Value (1-4) $^{\mathbf{3}}$} \\
\cline { 2 - 4 } & $\begin{array}{c}\text { Value of } \\
\text { experts - } \\
\text { professionals }\end{array}$ & $\begin{array}{c}\text { Value of } \\
\text { experts }- \\
\text { farmers }\end{array}$ & $\begin{array}{c}\text { Value } \\
\text { average rate }\end{array}$ \\
\hline 1. International grants (including EU) & 3,64 & - & 3,64 \\
\hline 2. Public (national) financial assistance & 3,60 & 3,49 & 3,55 \\
\hline 3. EU's Common Agricultural Policy & 3,49 & - & 3,49 \\
\hline 4. Technological change (new technology) & 3,44 & 3,49 & 3,47 \\
\hline 5. Knowledge and information & 3,47 & 3,41 & 3,44 \\
\hline 6. EU Pillar I (direct payments) Policy & - & 3,43 & 3,43 \\
\hline 7. Domestic market & 3,39 & 3,41 & 3,40 \\
\hline 8. Legal system and legislation & 3,50 & 3,29 & 3,40 \\
\hline 9. The International market & 3,29 & 3,25 & 3,27 \\
\hline 10. Public solidarity with the agricultural / rural & 3,13 & 3,18 & 3,16 \\
\hline 11. Competitiveness at the national level & 3,05 & 3,23 & 3,14 \\
\hline 12. Competitiveness at the international level & 2,97 & 3,05 & 3,01 \\
\hline 13. Biodiversity, environment & 2,66 & 3,19 & 2,93 \\
\hline 14. Other EU policies (eg. Cohesion, environment) & 2,86 & 2,95 & 2,91 \\
\hline Value average rate & $\mathbf{3 , 2 7}$ & $\mathbf{3 , 2 8}$ & 3,30 \\
\hline
\end{tabular}

Rural development in Lithuania is often understood in isolation from agricultural activities, it is not integrated subsystems on national (political) or local (farm, local community) level. This would be justified if in practice there would be developed activities that are income-generating and employing local residents to replace the agricultural activity. However, this is due to a lack of rural population creativity, innovation, entrepreneurship, offered a variety of training programs and projects; proposing weekly economically based solutions. Rural population products produced and

\footnotetext{
${ }^{3}$ Assessment from 1 to $4 ; 1$ - lowest, 4 - highest.
} 
processed usually taught to realize the local and national markets with declining real purchasing power of citizens and continuing emigration is becoming increasingly difficult to sell.

Integration into the EU, the introduction of various EU legislation regarding quality, tax, labelling requirements, etc. for production, small-scale agricultural production, processing and direct sales have become very complex, so its volume significantly decreased. Modern equipment rarely used in small-scale processing is, so here is a characteristic a relatively high cost. In addition, the situation has deteriorated, both politically and financially encouraging older people to get out before the pension payment of unemployment and other allowance.

In the period of 2007-2013 rural development policy measures are in favour orientation to the local markets, tourist attraction perhaps is effective in other developed EU Member States case, but in Lithuania it is still paying off the small and medium-sized farms and income, and non-agricultural agricultural activities, farmers receiving. However, if in rural areas will be promoted agricultural multi-functionality (social, environmental and economic effects), agricultural activities and its products will be innovative, integrated into other activities and local economy and they may increase rural competitiveness and prosperity of rural communities.

\section{CONCLUSIONS AND DISCUSSION}

The support from the EU and the national funds is not fully in line with the current concept of farms' modernization and agricultural innovation. As a result, farms can only create a partial capacity to adapt to changing environmental conditions. There remains a high dependence of small and medium-sized farms' development on the EU and national support in Lithuania.

According to experts, political factors have the highest impact for prosperity of the farms and agricultural companies in Lithuania (as compared to the technical-entrepreneurial, ethical-social factors, and intangible values).

According to the perspective of rural stakeholders and major players (farmers, scientists, politicians and municipal officers), the new concept of prosperity in Lithuanian rural areas should include 5 key elements (in order of importance): development of the rural social infrastructure and implementation of information technologies; strong self-governance, social awareness and partnership; high culture of life and communication; Rural employment and job creation in rural areas, population welfare; economic and social viability, ecology and environmental security of the countryside.

The survey results will provide decision-makers with proposals for rural development policies improvement in order to speed up the modernization of farms, good experience implementation in practice, to balance the development of rural areas and to ensure sustainable urban - rural integration links. It is necessary to promote innovations in agricultural management, marketing of agricultural products in the context of sustainable rural development.

Acknowledgements. This research was possible to implement due to financial support from Lithuanian Ministry of Agriculture.

\section{REFERENCES}

1. Bene, C., Newsham, A., Davies, M. 2013. Making the Most of Resilience. Research and analysis from the Institute of Development Studies. IDS In Focus Policy Briefing, Iss. 32, February, 2013. Available at http://www.ids.ac.uk/publication/making-the-most-ofresilience (accessed on 10/06/2015)

2. Boto, I., Pandya-Lorch, R., Biasca, R. 2013. Agricultural resilience in the face of crisis and shock. International food research Institute. Briefing n. 30. Available at: http://brusselsbriefings.net/past-briefings/agricultural-resilience/ (accessed on 10/06/2015).

3. Christopherson, S., Michie, J., Tyler, P. 2010. Regional resilience: theoretical and empirical perspectives. Cambridge Journal of Regions, Economy and Society, No. 3, pp. 3-10. http://dx.doi.org/10.1093/cjres/rsq004

4. Commission Implementing Regulation (EU) No 808/2014 of 17 July 2014 laying down rules for the application of Regulation (EU) No 1305/2013 of the European Parliament and of the Council on support for rural development by the European Agricultural Fund for Rural Development (EAFRD).

5. Darnhofer, I. Lamine, C., Knickel, K. 2013. Conceptual Framework for RETHINK. P.29. Available at: https://www.wiso.boku.ac.at/fileadmin/data/H03000/H73000/H73300/Ika/2013_RETHINK_ConceptualFW.pdf (accessed on 20/06/2015)

6. De los Ríos-Carmenado, I., Rahoveanu, T. A., Gallegos A. A. 2014. Project management competencies for regional development in Romania: analysis from "Working with People" model //1st International Conference "Economic Scientific Research Theoretical, Empirical and Practical Approaches", ESPERA, 2013.

7. IFRC. 2012. The Road to Resilience: Bridging relief and development for a more sustainable future. Available at http://www.ifrc.org/PageFiles/96178/1224500-Road\%20to\%20resilience-EN-LowRes\%20\%282\%29.pdf_ (accessed on 10/06/2015).

8. Jackson, T. 2009. Prosperity without growth: Economics for a Finite Planet. Earthscan, London.

9. Knickel, K., Zemeckis, R., Tisenkopfs, T. 2013. A critical reflection of the meaning of agricultural modernization in a world of increasing demands and finite resources. Rural development 2013: The Sixth International Scientific Conference, Akademija proceedings. Aleksandras Stulginskis University. Vol. 6, Book. 1, pp.561-567.

10. Lietuvos kaimo plètros 2007-2013 metų programos tarpinis vertinimas 2010. Galutinè vertinimo ataskaita. LRŽŪM. (In Lithuanian).

11. Lietuvos kaimo plètros 2007-2013 metų programos 2012 metų pažangos ataskaita 2013. Vilnius: LR Žemès ūkio ministerija. (In Lithuanian).

12. Lietuvos kaimo situacija 2014-2020 m. 2014. Vilnius, 15 p. (In Lithuanian). 
13. Lietuvos KPP 2014-2020. 2015. (Lithuanian Rural Development Programme 2014-2020). Available at https://www.nma.lt/index.php/parama/lietuvos-kaimo-pletros-2014-2020-m-programa/apie-programa/4911 (accessed on 10/06/2015).

14. Melnikienė, R. 2012. Pasiūlymai dẻl Lietuvos žemès ūkio Strateginių krypčių po 2013 metų, plètojant žaliosios knygos „Lietuvos kaimo ateitis" tikslus. Vilnius: LAEI, 41 p. (In Lithuanian).

15. Mokslinès rekomendacijos dèl žemės, maisto ūkio, žuvininkystès ir kaimo plètros taikomujų mokslinių tyrimų bei inovacijų plètros 2014-2020 m. 2013. Galutinė ataskaita 2013 m., Tyrimo vadovas Egidijus Šarauskis. Akademija, Kauno r. (In Lithuanian).

16. Oxfam (2009). People-Centred Resilience. Oxfam Briefing Paper 135. Boston: Oxfam America. Available at: http://www.oxfamamerica.org/publications/people-centered-resilience/ (accessed on 10/06/2015).

17. Potential Challenges to U.S. Farm Subsidies in the WTO. 2007. Prepared by Randy Schnepf and Jasper Womach. Resources, Science, and Industry Division. Available at: http://nationalaglawcenter.org/wp-content/uploads/assets/crs/RL33697.pdf (accessed on 10/06/2015).

18. Vidickienė, D., Melnikienė, R., 2014. Kaimo politikos evoliucija: monografija. (Rural Policy evolution: monography). Vilnius: LAEI, 272 p. (In Lithuanian).

19. Žalioji knyga: Lietuvos kaimo ateitis. 2010. (Green Paper “The Future of Rural Lithuania”). Vilnius, 31 p. (In Lithuanian). 